\title{
PENGARUH PENGGUNAAN YOUTUBE SEBAGAI MEDIA PEMBELAJARAN TERHADAP KETERAMPILAN MENULIS TEKS PROSEDUR SISWA KELAS VII SMP RK DELI MURNI BANDAR BARU
}

\author{
Immanuel D. B. Silitonga ${ }^{1}$, Asnita Hasibuan ${ }^{2}$ \\ ${ }^{1}$ Dosen Universitas Katolik Santo Thomas \\ ${ }^{2}$ Dosen Universitas Katolik Santo Thomas \\ Emai: immanuel814@gmail.com ${ }^{1}$, asnita103hasibuan@ gmail.com ${ }^{2}$
}

\begin{abstract}
ABSTRAK
Penelitian ini adalah penelitian kuantitatif yang bertujuan untuk mendeskripsikan pengaruh penggunaan youtube sebagai media pembelajaran terhadap keterampilan menulis teks prosedur siswa kelas VII SMP RK Deli Murni Bandar Baru. Metode penelitian yang digunakan dalam penelitian ini adalah pra eksperimen (praexsperimental design) dengan rancangan penelitian one grouppretest-posttest design. Pengumpulan data dilakukan dengan teknik tes yang terbagi menjadipretest dan posttest. Analisis data yang dilakukan pada penelitian ini adalah statistik deskriptif dan statistik inferensial. Hasil penelitian menujukkan bahwa penggunaan media youtube berpengaruh terhadap keterampilan menulis teks prosedur siswa kelas VII SMP RK Deli Murni Bandar Baru.
\end{abstract}

Kata kunci: media youtube, media pembelajaran, teks prosedur

\begin{abstract}
This study is a quantitative study that aims to describe the effect of using YouTube as a learning medium on the writing skills of the seventh grade students of SMP RK Deli Murni Bandar Baru. The research method used in this research is a pre-experimental design (pre-experimental design) with a one group pretest-posttest research design. Data was collected using a test technique which was divided into pretest and posttest. Data analysis carried out in this study were descriptive statistics and inferential statistics. The results of the study show that the use of youtube media has an effect on the writing skills of the seventh grade students of SMP RK Deli Murni Bandar Baru.
\end{abstract}

Key Words: youtube media, learning media, procedural text

\section{PENDAHULUAN}

Keterampilan menulis sangat diperlukan oleh semua kalangan, keterampilan menulis merupakan penyampaian pendapat yang berbentuk tulisan yang disusun dalam sebuah kalimat. Ketika seseorang salah menyampaikan kalimat dalam menulis, hal tersebut akan menimbulkan konfik. Maka dari itu, keterampilan menulis yang baik diperlukan disetiap kalangan

Dalam menulis, ketepatan dalam menyusun gagasan dan penyusunan kosakata yang tepat sangat diperlukan. Menulis bukan hanya sekedar menyampaikan pendapat, keterampilan menulis juga memiliki peraturan agar apa yang kita tulis dapat sampai kepada pembaca dengan baik. Menulis juga harus mengikuti unsur penting seperti 
meninjau dari segi tuturan dan tatanan.

Pembelajaran bahasa Indonesia $\mathrm{p}$ ada kurikulum 2013 lebih menekankan pada pembelajaran berbasis teks. Pembelajaran bahasa berbasis teks, bahasa Indonesia diajarkan bukan sekadar sebagai pengetahuan bahasa, melainkan sebagai teks yang mengembang fungsi untuk menjadi sumber aktualisasi diri penggunanya pada konteks social budaya academia Ramadania, 2016). Teks dimaknai sebagai satuan bahasa yang mengungkapkan makna secara kontekstual, sehingga dalam pembelajaran teks, siswa diharapkan mampu memproduksi dan menggunakan teks sesuai dengan tujuan dan fungsi sosialnya Devi dan Mulawarman (2018). Salah satu materi pembelajaran bahasa Indonesia dalam kurikulum 2013 ditingkat SMP kelas VII adalah materi teks prosedur. Penelitian ini berfokus pada keterampilan siswa dalam menulis teks prosedur. Hal ini terlihat dalam silabus kurikulum 2013 pada kompetensi dasar 4.6 yaitu menyajikan data rangkaian kegiatan kedalam bentuk teks prosedur dengan memperhatikan struktur, unsure kebahasaan, dan isi secara lisan dan tulis. Berdasarkan kompetensi dasar 4.6 menunjukkan bahwa materi teks prosedur sangat penting dan diharapkan siswa kelas VII mampu menyajikan atau menulis teks prosedur sesuai dengan struktur dan ciri kaidah kebahasaannya. Namun pada kenyataannya keterampilan siswa untuk menulis teks prosedur masih rendah.

Berdasarkan hasil wawancara dengan guru bahasa Indonesia di SMPRK Deli Murni Bandar Baru diperoleh informasi bahwa setelah guru bahasa Indonesia menerangkan definisi tentang teks prosedur beserta contohnya, mereka langsung bisa membuat teks prosedur baik itu melalui media cetak dan guru mata pelajaran bahasa Indonesia menyatakan kelas tersebut, dalam pembelajaran menulis teks prosedur masih sebagian kurang memahami.

Keadaan yang terlihat di lapangan menunjukkan bahwa terdapat beberapa factor yang menyebabkan rendahnya keterampilan menulis siswa, seperti sulitnya siswa dalam mengkomunikasikan pengetahuannya ke dalam bentuk tulisan yang disebabkan pemahaman yang digunakan hanya sebatas teori saja. Faktor lainnya disebabkan oleh media pembelajaran yang digunakan adalah media cetak yaitu sifatnya monoton. Hal itu sejalan Dengan pendapat Adah, dkk (2016) dalam jurnalnya berjudul "Pembelajaran Menulis Teks Prosedur Berdasarkan Hasil Wawancara di Kelas VIII-A1 SMP" bahwa untuk mendapatkan tulisan yang baik, guru tidak hanya berperan sebagai pengajar, tetapi juga harus kreatif dalam pembelajaran untuk menciptakan pembelajaran yang tidak monoton, dengan begitu siswa akan mendapatkan tulisan yang baik. Hasil yang sama juga diperoleh oleh Purba dalam penelitiannya (2012) menyatakan bahwa keterampilan siswa dalam menulis rendah. Hal tersebut, disebabkan karena siswa hanya diajarkan untuk terampil menguasai teori menulis dari pada terampil dalam menerapkannya. Pembelajaran menulisakan membosankan bila siswa hanya diajarkan secara teori tanpa mempraktikkan langsung. Keadaan itulah yang juga menyulitkan siswa dalam pembelajaran menulis teks prosedur, karena pembelajaran menulis teks prosedur membutuhkan praktik secara langsung dan siswa dituntut aktif dan kreatif.

\section{KAJIAN KEPUSTAKAAN}

Dalam menciptakan pembelajaran yang efektif, guru 
dituntut mampu menciptakan pembelajaran yang kreatif dan inovatif sehingga mendorong siswa untuk aktif selama proses pembelajaran berlangsung. Guru sebagai pengelola pembelajaran seharusnya berperan dalam menciptakan suasana belajar yang memungkinkan siswa dapat belajar dengan menyenangkan melalui media pembelajaran.

Menurut Sudjana dan Ahmad (2013), manfaat media pembelajaran dalam proses belajar siswa antara lain: (1) pembelajaran lebih menarik perhatian siswa sehingga dapat menumbuhkan motivasi belajar, (2) bahan ajarakan lebih jelas maknanya sehingga dapat lebih dipahami oleh siswa, dan memungkinkan siswa menguasai tujuan pengajaran lebih baik, (3) metode pembelajaran akan lebih bervariasi, tidak hanya dengan komunikasi verbal melalui penuturan kata-kata oleh guru, siswa juga diajak untuk berperan aktif dalam pembelajaran sehingga meminimalisir kejenuhan saat mengikuti pembelajaran, dan (4) siswa lebih banyak melakukan kegiatan belajar, sebab tidak hanya mendengarkan uraian guru, tetapi juga aktivitas lain seperti mengamati, melakukan, dan mendemonstrasikan. Salah satu media yang dapat digunakan oleh guru adalah media video. Media video termasuk dalam media audio visual yang merupakan perpaduan antara suara dan gambar yang secara bersamaan dapat didengar dan dilihat.Daryanto(2012) menguraikan kegunaan media video, yaitu: (1) memperjelas pesan agar tidak terlalu verbalistis, (2) mengatasi keterbatasan ruang, waktu, tenaga dan daya indera, (3) menimbulkan gairah belajar, interaksi lebih langsung antara siswa dengan sumber belajar, (4) memungkinkan siswa belajar sesuai dengan bakat dan keterampilan visual, auditori, dan kinestetiknya, memberi rangsangan yang sama, mempersamakan pengalaman, dan menimbulkan persepsi yang sama, dan (6) proses pembelajaran mengandung lima komponen komunikasi, yaitu guru (komunikator), bahan pembelajarn, media pembelajaran, siswa (komunikan), dan tujuan pembelajaran. Jadi, media pembelajaran adalah segala sesuatu yang dapat digunakan untuk menyalurkan pesan (bahan ajar) sehingga dapat merangsang perhatian, minat, pikiran, dan perasaan siswa dalam kegiatan belajar untuk mencapai tujuan pelajaran. Karena tidak hanya menghibur dengan tampilan-tampilan untuk ditayangkan dalam video, tetapi juga dapat menambah wawasan baru kepada siswa dengan infor masih up to date.

\section{METODE}

Penelitian ini merupakan jenis penelitian kuantitatif. Adapun penelitian ini termasuk jenis penelitian pra eksperimen (pre-experimental). Desain penelitian menggunakan one group pretest dan post-test. Populasi pada penelitian ini yaitu kelas VII SMP RK Deli Murni Bandar Baru yang berjumlah 218 siswa dengan mengambil sampel kelas VII-1 sebanyak 35 siswa. Pengambilan sampel dilakukan dengan teknik simple random sampling.

Teknik pengumpulan data pada penelitian ini berupa teknik tes. Tes yang dimaksud terbagi dua bagian yaitu pretest dan posttest. Teknik analisis data yang digunakan adalah statistic deskriptif dan statist ikin ferensial.

\section{HASIL}

\section{Hasil Belajar Menulis Teks Prosedur Sebelum Menggunakan Media Youtube}

Hasil belajar siswa pada 
pembelajaranmenulis teks prosedur sebelum menggunakan media youtube dengan analisis statistic dekriptif. Analisis statistik deskriptif menggambarkan perolehan hasil belajar siswa mulai yang tertinggi hingga yang terendah dengan hasil interpretasi berkaitan dengan nilai pretest siswa. Interpretasi hasil belajar siswa dalam menulis teks prosedur sebelum menggunakan media youtube ditunjukkan pada table berikut.

Tabel 1. Interpretasi Hasil Belajar Menulis Teks Prosedur pada Pretest

\begin{tabular}{|c|c|c|c|}
\hline No & Interval & Frekuensi & $\begin{array}{c}\text { Persentase } \\
(\%)\end{array}$ \\
\hline 1 & $90-100$ & 0 & 0 \\
\hline 2 & $80-90$ & 0 & 0 \\
\hline 3 & $65-79$ & 7 & 20 \\
\hline 4 & $55-64$ & 7 & 20 \\
\hline$\underline{5}$ & $\underline{0-54}$ & $\underline{21}$ & $\underline{60}$ \\
\hline
\end{tabular}

sampel penelitian kelas VII.1 sebanyak 35 siswa. Pengambilan sampel dilakukan dengan teknik simple random sampling.

Teknik pengumpulan data pada penelitian ini berupa teknik tes. Tabel (1) menunjukkan bahwa penentuan patokan dengan perhitungan persentase hasil belajar berada pada kategori sangat baik memiliki nilai 90-100, kategori baik memiliki rentang nilai antara 80-90, kelompok cukup baik memiliki nilai antara 65-79, kategori kurang baik memiliki rentang nilai antara 55-64, dan kategori tidak baik memiliki rentang nilai 0-54 kebawah.

Hasil belajar dari pada keterampilan menulis teks prosedur sebelum menggunakan media youtube menunjukkan bahwa tidak seorang pun siswa yang memperoleh kategori sangat baik dan kategori baik. Perolehan nilai dapat diketahui bawah dari jumlah keseluruhan sampel yang ada, keterampilan siswa secara umum, yaitu sebelum menggunakan media youtube adalah mengalami perubahan. Keterampilan menulis teks prosdur pada saat pretest 7 orang siswa berada pada kategori cukup baik (20\%), dan kategori kurang baik sebanyak 7 orang siswa (20\%), dan kategori tidak baik sebanyak 21 orang siswa $(60 \%)$. Hal tersebut dapat dilihat dari frekuensi siswa yang mendapat rentang nilai 0-64 dengan jumlah siswa sebanyak 28 dan persentasenya $80 \%$ sedangkan rentang nilai 65-79 hanya ada 7 siswa saja dan persentasenya $20 \%$.

\section{Hasil Belajar Menulis Teks Prosur Se telah Menggunakan Media Youtube}

Hasil belajar siswa dalam menulis teks prosedur setelah menggunakan media youtube, digambarkan melalui analisis statistic deskriptif. Analisis deskriptif menggambarkan perolehan hasil belajar siswa mulai yang tertinggi hingga yang terendah. Hasil interpretasi berkaitan dengan hasil belajar pada post test. Interpretasi hasil belajar siswa dalam menulis teks prosedur setelah menggunakan media youtube ditunjukkan pada table berikut.

Tabel 2. Iterpretasi Hasil Belajar Menulis Teks Prosedur pada Pos test

\begin{tabular}{|l|l|r|r|}
\hline No & Interval & Frekuensi & $\begin{array}{r}\text { Persentase } \\
(\boldsymbol{\%})\end{array}$ \\
\hline 11 & $90-100$ & 7 & 20 \\
\hline 22 & $80-90$ & 8 & 23 \\
\hline 33 & $65-79$ & 8 & 23 \\
\hline 44 & $55-64$ & 6 & 17 \\
\hline 55 & $0-54$ & 6 & 17 \\
\hline
\end{tabular}

Tabel (2) menunjukkan bahwa penentuan patokan dengan perhitungan persentase hasil belajar berada pada kategori sangat baik memiliki rentang nilai 90-100, kategori baik memiliki 
rentang nilai 80-90, kategori cukup baik memiliki rentang nilai $65-79$, kategori kurang baik memiliki rentang nilai 5564 , kategori tidak baik memiliki rentang nilai 0-54 kebawah.

$$
\text { Hasil dari kategorisasi }
$$

keterampilan menulis teks prosedur setelah menggunakan media youtube menunjukkan bahwa ada 7 orang siswa memperoleh kategori sangat baik (20\%), 8 orang siswa berada pada kategori baik $(23 \%), 8$ orang siswa berada pada kategori cukup baik (23\%), 6 orang siswa berada pada kategori kurang baik (17\%), 6 orang siswa berada pada kategori tidak baik (17\%), diketahui bahwa dari jumlah keseluruhan sampel yang ada, keterampilan menulis siswa setelah menggunakan media youtube mengalami perubahan. Hal tersebut, dapat dilihat dari frekuen sisiswa yang mendapat rentang nilai $80-$ 100 dengan persentase $43 \%$ dan $23 \%$ berada pada kategori cukup baik.

\section{Pengaruh Media Youtube Terhadap Keterampilan Menulis Teks Prosedur} Berdasarkan hasil analisis data pretest dan posttest dapat diketahui pengaruh media youtube terhadap keterampilan menulis teks prosedur siswa kelasVII SMP RK Deli Murni Bandar Baru. Untuk menganalisis pengaruh media youtube terhadap keterampilan menulis teks prosedur, maka digunakan analisis statistic inferensial. Hasil analisis statistic inferensial bertujuan untuk menjawab hipotesis penelitian yang telah dirumuskan sebelumnya.Hasil analisis statistic inferensial ditunjukkan pada table berikut.

Tabel 3. Hasil Uji-t (Paired Sample T Test)

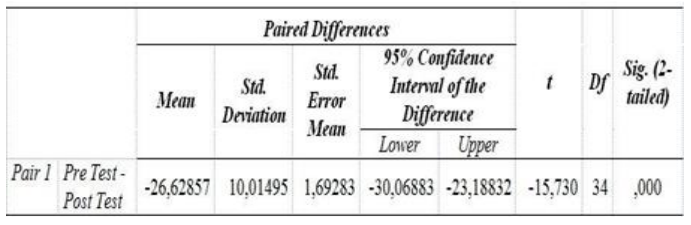

Berdasarkan uji

hipotesis menggunakan paired samples test pada table (3) menunjukkan bahwa nilai sigifikansi $0,000<\alpha 0,05$. Hal ini menunjukkan bahwa $\mathrm{H} 0$ ditolak dan $\mathrm{Ha}$ diterima yang berarti terdapat pengaruh penggunaan media youtube dalam keterampilan menulis teks prosedur terhadap siswa kelas VII SMP RK Deli Murni Bandar Baru.

\section{PEMBAHASAN}

Berdasarkan penyajian hasil penelitian, dapat diuraikan secara rinci tentang pengaruh penggunaan youtube sebagai media Pembelajaran terhadap keterampilan menulis teks prosedur siswa kelasVII-6. Penelitian ini dilakukan sebanyak 3 pertemuan, kegiatan pretest yang dilakukan secara online melalui aplikasi Whatsapp Group yang dimana siswa telah bergabung di dalamnya, sebanyak 35 siswa dan 1 orang guru Bahasa Indonesia untuk memantau siswa dan peneliti. Setelah itu peneliti memperkenalkan identitasnya dan menanyakan kepada siswa terlebih dahulu sebelum memberikan materi tentang teks prosedur. Pertemuan selanjutnya yaitu kegiatan pembelajaran kedua secara daring melalui aplikasi WhatsApp. Pada pertemuan ini, peneliti memberikan soal kepada siswa untuk membuat satu contoh teks prosedur sesuai tema yang dibuat oleh peneliti, berikutnya peneliti menjelaskan lebih jelas tentang teks prosedur yang dihadiri 35 siswa. Selanjutnya pertemuan ketiga secara daring melalui aplikasi WhatsApp Group. Peneliti member tugas kepada siswa yaitu membuat satu contoh teks prosedur dengan tema yang dibuat peneliti dengan menggunakan atau 
melihat tayangan di media youtube sesuai tema yang dipilih oleh siswa, setelah itu peneliti mengambil lembaran kerjasiswa di rumah masingmasing siswa. Kegiatan terakhir yaitu memeriksa hasil kerja siswa dengan acuan rubric penilaian teks prosedur sebanyak 35 siswa berbentuk pretest dan posttest. Uji persyaratan terlebih dahulu dilakukan sebelum uji hipotesis. Uji persyaratan yang dimaksud yaitu uji normalitas dan uji homogenitas.

Adapun pembelajaran menulis teks prosedur pada pretest tanpa menggunakan media youtube yaitu mengalami perubahan hasil belajar. Hal tersebut dapat dilihat dari hasil belajar siswa. 7 orang siswa berada pada kategori cukup baik (20\%), dan kategori kurang baik sebanyak 7 orang siswa (20\%), dan kategori tidak baik sebanyak 21 orang siswa $(60 \%)$. Hal tersebut, dapat dilihat dari frekuensi siswa yang mendapat rentang nilai 0-64 dengan jumlah siswa sebanyak 28 dan persentasenya $80 \%$ sedangkan rentang nilai 65-79 hanya ada 7 siswa (20\%).

Hasil belajar yang diperoleh siswa pada pretest mengalami perubahan, hal ini disebabkan kurang adanya gairah siswa dalam proses pembelajaran, sehingga siswa tidak termotivasi untuk menyelesaikan tugas dengan baik. Adapun ciri-ciri siswa yang memiliki motivasi belajar yang kurang baik sehingga mudah putus asa dalam mengerjakan tugas kurang bersemangat, dan memiliki hasil belajar yang rendah.

Adapun pembelajaran menulis teks prosedur dengan menggunakan media youtube cukup baik dibandingkan dengan posttest. Hal ini dapat dilihat dari hasil analisis statistic deskriptif yang menunjukkan bahwa siswa yang memperoleh rentang nilai 90-100 berjumlah 7 (20\%), siswa yang memperoleh rentang nilai 80-90 berjumlah 8 dengan (23\%),siswa yang memperoleh rentang nilai 65-79 berjumlah 8 (23\%), siswa yang memperoleh rentang nilai 55-64 berjumlah 6 (17\%), siswa yang memperoleh rentang nilai 0-54 berjumlah6 (17\%). Dapat diketahui bahwa dari jumlah keseluruhan sampel yang ada, keterampilan siswa setelah menggunkan media youtube adalah berkategori baik. Hal tersebut dapat dilihat dari frekuen si siswa yang mendapat rentang nilai 80-100 dengan persentase $43 \%$ dan $23 \%$ berada pada kategori cukup baik.

Penggunaan media youtube dalam pembelajaran menulis teks prosedur cukup menarik perhatian dan minat siswa dalam belajar, pada saat kegiatan menulis teks prosedur berlangsung siswa nampak lebih bersemangat. Pada umumnya siswa sudah mampu menangkap pesan yang terdapat dalam media youtube tersebut. Meskipun siswa masih memiliki kendala pada kaidah penulisan dan cirri kebahasaan yang belum variatif namun penguasaan dalam menulis teks prosedur menunjukkan hasil yang cukup baik.

Berdasarkan analisis data kelas eksperimen yang telah dilakukan maka untuk hasil belajar. Hal tersebut dapat dilihat dari hasil belajar siswa. 7 orang siswa berada pada kategori cukup baik (20\%), dan kategori kurang baik sebanyak 7 orang siswa (20\%), dan kategori tidak baik sebanyak 21 orang siswa (60\%). Hal tersebut, dapat dilihat dari frekuensi siswa yang mendapat rentang nilai 0-64 dengan jumlah siswa sebanyak 28 dan persentasenya $80 \%$ sedangkan rentang nilai 65-79 hanya ada 7 siswa (20\%). uji normalitas diketahui bahwa nilai $p=0.200$. Hal ini menunjukkan bahwa $\mathrm{p}>\alpha=0.05$ yang menyatakan bahwa data hasil hasil belajar menulis teks prosedur siswa kelasVII SMP RK Deli Murni Bandar Baru dari pretest dan posttest berdistribusi normal. Selanjutnya data tersebut telah memenuhi persyaratan 
untuk dianalisis. Kemudian uji homogenitas varian akan diperoleh nilai-nilai yang menunjukkan varian yang homogeny. Berdasarkan uji homogenitas yang diperoleh yaitu 0,155 $>\alpha 0,05$. Hal ini menunjukkan bahwa hasil belajar siswa memiliki varian homogen. Selanjutnya,berdasarkan uji hipotesis menggunakan paired samples test pada table (3) menunjukkan bahwa nilai sigifikansi $0,000<\alpha 0,05$. Hal ini menunjukkan bahwa $\mathrm{H} 0$ ditolak dan $\mathrm{Ha}$ diterima yang berarti terdapat pengaruh penggunaan youtube sebagai media pembelajaran dalam keterampilan menulis teks prosedur terhadap siswa kelas VII SMP RK Deli Murni Bandar Baru.

\section{SIMPULAN}

Berdasarkan uji hipotesis menggunakan paired samples test dan pengolahan hasil penelitian dari data berupa pretest dan posttest pada kelas eksperimen diperoleh hasil $0,000<\alpha$ 0,05 sehingga hasil penelitian menunjukkan adanya pengaruh penggunaan youtube sebgai media pembelajaran dalam keterampilan menulis teks prosedur siswa kelas VII SMP RK Deli Murni Bandar Baru.

\section{REFERENSI}

Adah, dkk. 2016. Pembelajaran Menulis Teks Prosedur Berdasarkan Hasil Wawancara di Kelas VIIIA1 SMP $N 1$ Singaraja.Jurnal Pendidikan Bahasa dan Sastra indonesia Undiska. 5 (3).

Daryanto. 2012. Media Pembelajaran. Bandung: Satu Nusa

Devi, dkk. 2018. Pengembangan Bahan Ajar Menulis Teks Prosedur Kompleks dengan Model Pembelajaran Discovery Learning. Samarinda. Diglosia: Jurnal Kajian Bahasa, Sastra, dan
Pengajarannya,1(2).

Purba, L. 2012. Pengaruh Model Kreatif Treffinger terhadap Keterampilan Menulis Narasi Sugestif. Jurnal Bahasa \& Sastra Indonesia, 9(1).

Ramadania, F. 2016. Konsep Bahasa Berbasis Teks pada Buku Ajar Kurikulum 2013. Stilistika: Jurnal Bahasa, Sastra, dan Pengajarannya, 1 (2).

Sudjana, dkk. 2013. Media Pembelajaran. Bandung: Sinar Baru Algesindo 